\title{
STAGING THE PAST: LANDSCAPE DESIGNS, CULTURAL IDENTITY AND ERINNERUNGSPOLITIK AT BERLIN'S NEUE WACHE
}

\author{
Karen E. Till
}

\begin{abstract}
The controversies surrounding the re-establishment of a national memorial in Berlin, the Neue Wache, are examined to discuss the process of public memory. After unification, West German media continued to define public debate. 'Established' interest groups (politicians, victims, historical experts and citizen groups) were included in media discussions whereas others (East Germans, marginalized groups) were not. Criticisms about the function, form and 'forgetfulness' of the memorial reflected West German memory politics (Erinnerungspolitik) about the historical uses of: national institutions, religious (but not gendered) national symbols, and social categories of victim and perpetrator. In response to criticisms, a plaque was added to the memorial. Locally, activists created inclusive spaces to address critically the meaning of the National Socialist past in contemporary landscapes. The memorial is thus both a material object and a site of negotiation; it remains 'entangled' with the ongoing creation of historical narratives, official visions, local memories and cultural productions.
\end{abstract}

\begin{abstract}
A fter the Bundestag voted for Berlin as the new seat of government for a united Federal Republic in 1991, the reconstruction of the city centre accelerated. The sum of $\$ 135$ billion has been devoted to this massive urban renewal project by the federal government and the city of Berlin (Figure 1). Former icons of the East-West division are being replaced by new government and business complexes, including the former 'death strip' at Potsdamer Platz (the wide zone between the East and West Berlin Walls which spanned several hundred feet), Pariser Platz at the Brandenburg Gate, Checkpoint Charlie, and the area around the Reichstag. As Berlin's city building director, Hans Stimann, explained, 'Berlin is the only place in the world where the centre is empty. It's like an operation on the heart without the rest of the body feeling anything.' ${ }^{1}$
\end{abstract}




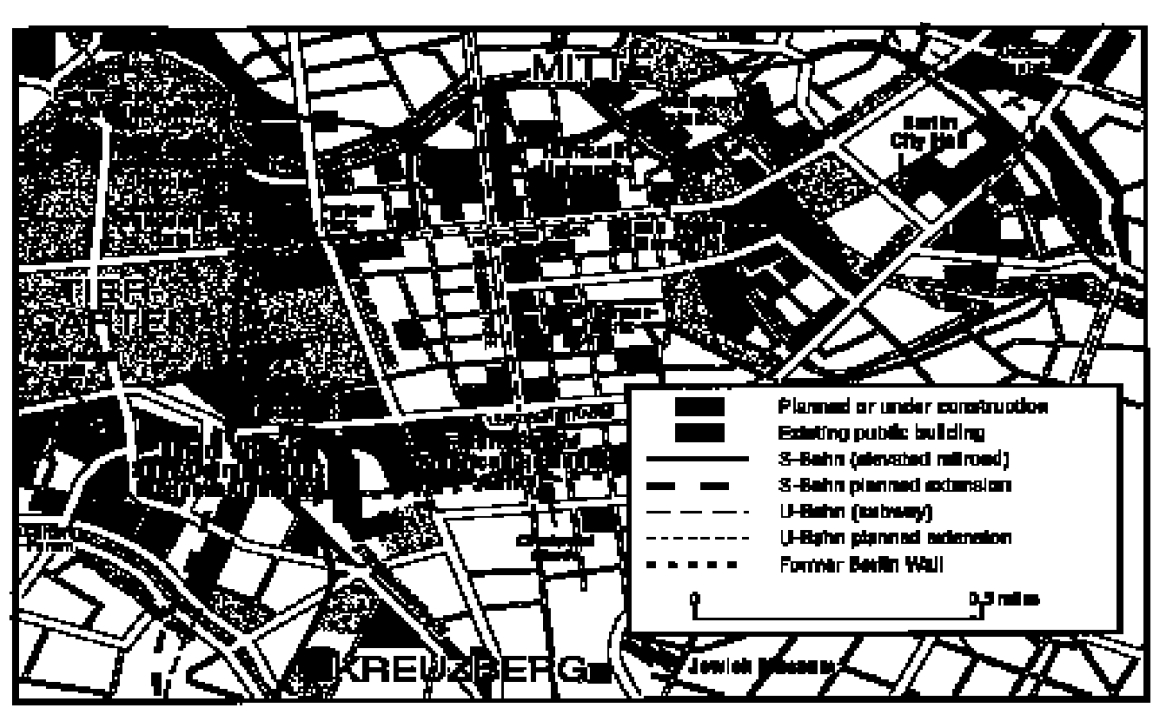

Figure $1 \sim$ Map of urban renewal sites in the district of Berlin-Mitte in grey (source: National Geographic Dec. 1996, p. 105)

Stimann's quote characterizes one way of viewing the new Berlin. From a planner's perspective, the Cold War spaces that once bisected the city can be depicted as red zones on maps, sites where the necessary economic 'operation on the heart' will create an European megalopolis of the twenty-first century. ${ }^{2}$ Such maps and descriptions of Berlin have become a prevalent way of representing the city because of the unprecedented scale of physical construction, and because (West) Berlin will no longer be subsidized by the Federal Republic and must rebuild its economy. Yet what is missing from the planner's perspective are the views of local residents who must live in these changing landscapes. In this paper I argue that many Berliners do not see their city centre as 'empty' but rather as historically rich, complex built environments that embody the contradictory meanings of being German.

One way to understand the social changes following unification from both the national and local scales is through an examination of public monuments. As Nuala Johnson and others have argued, the study of landmarks offers us insights into the ways nationalist political discourses are articulated. ${ }^{3}$ Moreover, because the creation of official landscapes is a process involving many social groups, a study of one place can help us understand how citizens interpret, use and contest their urban public spaces. A focus on the negotiation of cultural identities at a particular site of memory in Berlin following unification may be especially insightful when symbolic systems, social relations, expectations of the state and everyday landscapes are in flux. ${ }^{4}$

In this article, I examine the public debates about one memorial with a complex history, the Neue Wache (or 'New Guardhouse') (Figure 2). Originally built in 1816-18 as the Prussian king's palace guard, the neoclassical pavilion was redesigned as a war memorial during the Weimar Republic and again during 


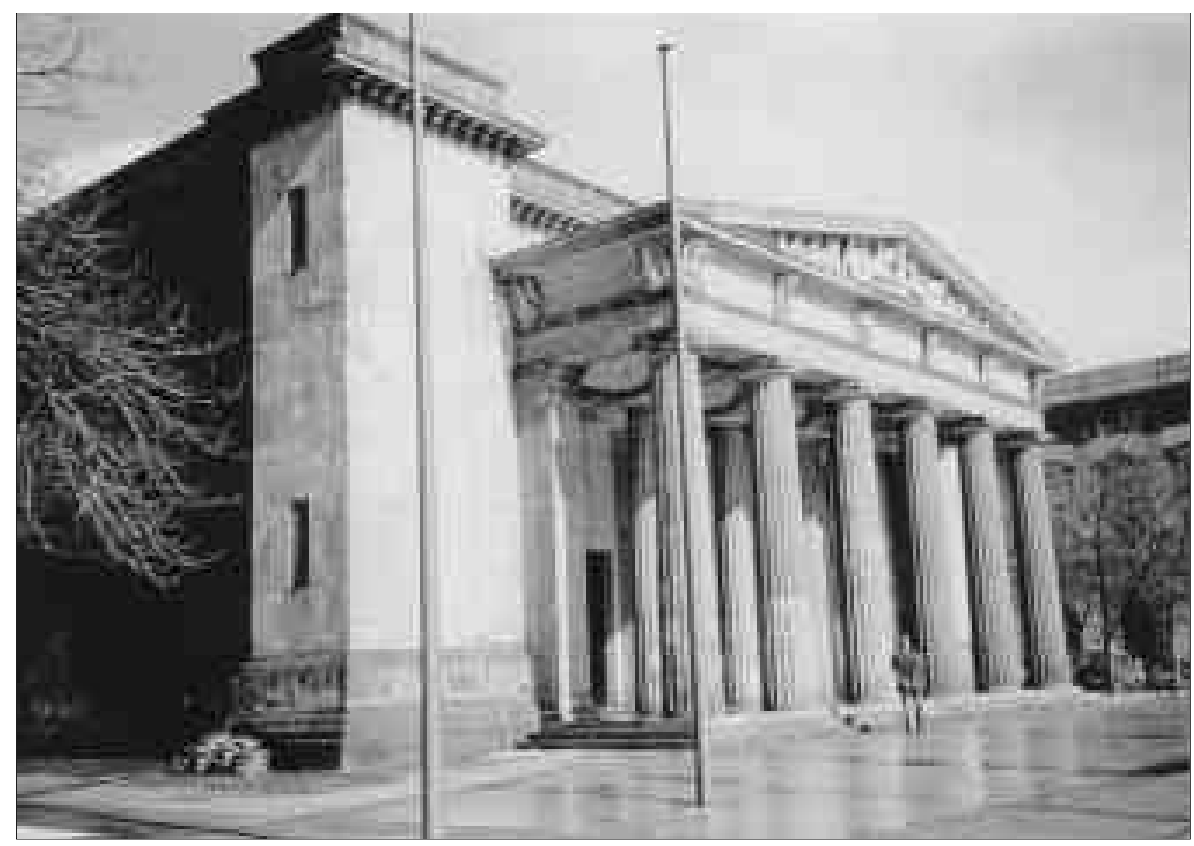

Figure $2 \sim$ The redesigned Neue Wache memorial on Unter den Linden in 1994 (photograph taken by the author)

the Nazi regime. After the Second World War it functioned as the East German site for commemorating 'victims of fascism'. Following unification, the Neue Wache was declared the 'new' unified German national memorial for 'victims of war and oppression'. After setting up this historical context, I describe the negotiation of public memory at the site as it appeared in the printed press in 1992-93. In the case of the Neue Wache, the national media framed much of the debate about collective identity and the relationship to the Nazi past according to representations of four West German interest groups: politicians, victims, historical experts and citizen initiatives. Consequently, I suggest that East Germans, among other marginalized groups, were excluded from participating in this (West) German 'public' realm.

Within the confines of the (West German) media debates, criticisms were raised regarding the approval process of the memorial and about the function, form and 'forgetfulness' of the Neue Wache. Concerns articulated by critics can be seen as a response to the historical uses of national institutions in Germany, a sensitivity to exclusive religious (but not gendered) symbols to represent the nation and a difficulty in reconciling the social categories of victim and perpetrator in past, present and future. As a result of these criticisms - and, significantly, in response to a longer postwar set of discussions about dealing with the National Socialist past - officials modified the memorial somewhat before its unveiling in 1993. At the same time, Berlin activists, whose voices were muted in the national press, created alternative cultural realms to explore the history 
of commemoration in Germany. These citizen groups expanded the parameters of debate (as traditionally defined by the media) and provided the possibility of a more inclusive process of public memory, at least locally.

The Neue Wache today is a well-visited traditional commemorative place, as well as a site of negotiation where official and collective memories, media representation and local cultural productions become enmeshed. Before describing its history and the debates surrounding its establishment, I first outline the themes of landscape and memory that inform this study.

\section{Landscape and public memor y}

There is a large literature on official urban landscapes of memory - museums, memorials and monuments - as stages or backdrops framing myths of national identity. ${ }^{5}$ Boyer calls such spaces 'rhetorical topoi ... those civic compositions that teach us about our national heritage and our public responsibilities and assume that the urban landscape itself is the emblematic embodiment of power and memory.' ${ }^{\prime}$ The creation of rhetorical topoi, of official landscape stages, is both a dramaturgical and a territorial act. Cultural practices and rituals, such as laying wreaths at national memorials or festive parades that take place along a prescribed route, 'naturalize' a collective identity as citizens physically enact what is normal, appropriate or possible for a group at a particular setting. ${ }^{7}$ Of course, social groups may not agree with the official meanings of these landscapes and staged rituals; they may decide to take over existing topoi or create their own sites of memory. These more localized territorial struggles over the meanings of the built environment often reflect larger social (and power) disputes about who has the authority to create, define, interpret and represent collective pasts through place. ${ }^{8}$

Yet popular memory should not be conceived only as a binary opposite to official memory. Rather, public memory results from a more fluid process of negotiation between officials, local groups, academics, journalists and others in the cultural sphere. ${ }^{9}$ As Marita Sturken has argued, public memory can be thought of as 'entangled' with the very objects of its negotiation, entities that include historical narratives, official memory, collective memories, landscapes, narratives, films and other cultural productions. ${ }^{10}$ Here I define 'collective memory' in Jonathan Webber's terms as the dynamic process by which groups map myths (in an anthropological sense) about themselves and their world onto a specific time and place. ${ }^{11}$ Collective memory therefore is not an accumulation of individual recollections; rather, it includes all the activities that go into making a version of the past resonate with group members. ${ }^{12}$ Because collective identities are defined in part by perceived group needs in the present and projected future, these social narratives about the past are always changing.

If group myths are continuously in flux, one way to provide a sense of temporal stability is by projecting narratives about the past onto places and/or their representations. For example, in describing the history of Christian group identity, Maurice Halbwachs argued that the earliest religious rituals were most 
successful when a story had a 'double focus', a tangible object like a monument or place, and a shared group symbol that was 'superimposed on this physical reality'. ${ }^{13}$ Similarly, geographers have defined landscapes as duplicitous because on the one hand they are materially experienced (that is, we can touch, see, smell and taste our surroundings), while on the other they can simultaneously function as social symbols. During times of social unrest, for example, a group may use culturally familiar and comforting images (such as an ancient castle or rugged mountain peak) to project a stable picture of reality. As Halbwachs and Lowenthal suggest, the image of permanence projected by a landscape feature is often more important than historically accurate information about the place in legitimating a group's sense of self. ${ }^{14}$

If collective memory involves the ongoing process of creating group myths about the past as, for example, expressed through landscapes and their representations, then public memory is the cultural space and process through which those myths are understood, interpreted and negotiated by a society. Where this cultural memory of a 'people' is expressed, according to Sturken, is 'outside the avenues of formal historical discourse yet is entangled with cultural products and imbued with cultural meaning'. ${ }^{15}$ In other words, the cultural arena, rather than the academy, is the domain of public memory. Through various forms of the media, cultural landscapes, social institutions and the marketplace, public memory is valued and communicated by social groups. In contrast, historical narratives are more narrowly defined according to communities of scholars, formal university institutional networks, publishing firms and public and private granting establishments. As such, the practice of history and the process of public memory often overlap; within the cultural realm, for example, groups may selectively use the products of historical discourse to obtain social support for their goals. ${ }^{16}$

To reiterate, public memory is where and how groups struggle to gain cultural authority to selectively represent and narrate their past. Part of that process includes the creation and appropriation of landscapes, cultural objects, narratives (and here I include formal histories) and images by groups to support their social myths of identity. When and where collective memories come into conflict, as is often the case at particular places or through their representations, the results can be quite politicized. Public memory therefore can belong to the domain of cultural politics 'where (social) meanings are negotiated and relations of dominance and subordination are defined and contested'. ${ }^{17}$

In the sections that follow, I describe the entanglement of public memory official and local views of the past that intersect, define, and are defined by historical narratives, the printed press (newspaper articles and books), and cultural productions (demonstration and exhibition) - at the Neue Wache. Because historical narratives about this memorial have been used and produced by different groups to support their interpretations, I offer a brief chronological sketch of the Neue Wache as a context to the public debates. Following this overview, I discuss the role of the media, West German social relations and the criticisms and cultural productions that have influenced the form and interpretations of the memorial. 


\section{Staging the past: of ficial memory at the Neue Wache}

The Neue Wache $e^{18}$ is located along Unter den Linden in what is known as the historic district of Berlin, a part of the city that dates back to at least the seventeenth century. At this time Berlin's City Palace, built upon the foundations of the medieval fortress, was the symbolic centre of the city. From the creation of Unter den Linden in 1647 by Friedrich Wilhelm, the Great Elector who created a royal Prussia, the grand boulevard functioned as the city's main thoroughfare and ritual space. Over the next 200 years, various buildings and monuments were built along the processional route. ${ }^{19}$ For example, in 1791 Friedrich Wilhelm II sought to change the warmongering image of Prussia associated with his predecessor, Frederick the Great (King Friedrich II), and built the Brandenburg Gate along Unter den Linden as a symbol of peace. When Napoleon captured Berlin in 1806, he stormed through the gateway to capture the 'heart' of the city, a dramatic entrance intended to signal the beginning of a republican era. This phase was short-lived and in 1814, the triumphant Prussian king re-entered the city through the renamed 'Victory Gate' along the Prussian via triumphalis, or Unter den Linden. ${ }^{20}$

Upon his return to Berlin, King Friedrich Wilhelm III sought to end the liberal reforms of the Napoleonic period and return to the pre-1806 ancien régime. Between 1815 and 1848 Prussia oscillated between local monarchy and core territory of an emerging German nation-state. ${ }^{21}$ In response to calls for democratic reforms and social instability following French occupation, the king sought to legitimate the monarchy through a redesigned, monumental royal city centre. These plans, including the construction of a royal palace guard (the Neue Wache), bore witness to citizens and visitors that Prussia not only had defeated Napoleon but was becoming a growing power in Europe.

\section{Prussia's royal guard}

The king commissioned his new head architect, Karl Friedrich Schinkel, to build the Neue Wache and propose designs for the new city centre. Schinkel would become internationally famous for this work and his neoclassical projects left a lasting imprint on the city's built environment. ${ }^{22}$ Schinkel's palace guardhouse was a classical monument, a synthesis of Roman castrum and Greek temple that exaggerated the structure's material and symbolic presence. The frontal portico of six double rows of Greek Doric columns created deep recesses and dramatic shadows that contrasted with the solid, cubic structure. The crisp edges of the building were emphasized by the soft foliage of chestnut trees planted around the structure.

Although the pavilion was small, it was located near important royal buildings including the baroque Prussian Armory (the Zeughaus), the City Palace, the Opera House and the Palace of Prince Heinrich (later the Friedrich Wilhelm University). Schinkel's design for the Neue Wache reflected his larger plans for the renovation of Unter den Linden. He envisioned Prussia's via triumphalis as 
a ceremonial boulevard lined with neoclassical buildings, classical mythological sculptures, public monuments and graceful trees along which military parades would progress. From at least the early nineteenth century, therefore, the streetscapes of Unter den Linden were intended as a monumental and orderly projection of royal power. ${ }^{23}$ Later, in the mid- to late nineteenth century, this symbolic promenade came to represent the rise of Berlin from royal seat to capital city. Citizens would gather along the boulevard and visit the museums, university, library, opera house, theatres, embassies and cathedrals now located in the city centre, many of which were built or redesigned by Schinkel. The grandeur of this urban landscape image - of romantic vistas, ornate buildings, elite cultural institutions and parading armies and citizens - often concealed political conflicts within the monarchy and within a society that was moving toward the creation of the modern state ultimately established in 1871 .

\section{The Neue Wache as a national war memorial}

When the monarchy ended in 1918, the Neue Wache lost its function as the royal palace guard. Its ceremonial function, however, was maintained, for in 1930 the state erected a memorial to commemorate Germany's fallen soldiers in the First World War (Gedächtnisstätte für die Gefallenen des Weltkrieges). The material and symbolic transformation of the Neue Wache into a war memorial occurred during what Gillis defines as a 'national phase of commemoration', a historical period when the dead, rather than the living, symbolized the nation and in which temporal frameworks of identity were selectively defined by male elites. ${ }^{24}$ It was a form of commemoration that reified the division between a masculine public sphere and a feminine private sphere by encouraging visitors to view the fallen soldiers as Germania's lost sons. The brave soldiers who defended national boundaries and died protecting their homeland (figured as the sphere of women and children) were commemorated (by an overwhelmingly male officialdom) through statuary in the public spaces of the capital city. Heroes were remembered as actors in the life-history of the nation; at such national memorials women were simply ignored. ${ }^{25}$

The interior of the Neue Wache was redesigned by Heinrich Tessenow in 1931. A large gold- and silver-plated oak wreath was set atop a two-metre-high black marble block in the centre of the room's sleek granite floors, and illuminated by a shaft of light coming through a circular opening in the ceiling. Although Tessenow's interior space was modern for its day, the sculptural forms evoked traditional aesthetics commonly found at First World War cemeteries. According to Winter, public art found at cemeteries built after 1918 emphasized a universal language to communicate their message, simultaneously drawing on and transcending particular traditions. ${ }^{26}$ The oak wreath at the Neue Wache was clearly a symbol of nationalist ideals, for "Nature herself was to serve as a living memorial ... The oak, whose symbolic strength had been invoked during the Wars of Liberation, was considered the "German tree". ${ }^{27}$ Oak trees had become memorials at German military cemeteries: Heldenheine, or heroes' groves, stood strong, yet alone, in a field. The memorial's marble block also symbolized primeval 
power; the boulder, like the oak tree, was used in German war monuments to emphasize the strength of the nation and an ideal of the genuine and enduring, as opposed to the modern. These traditional symbols of nature were literally illuminated at the Neue Wache by the shaft of light coming through the ceiling, an architectonic form connecting the nation to antiquity through its reference to the Pantheon. ${ }^{28}$

It is difficult today to ascertain how individuals and groups experienced this memorial. Whalen, for one, has suggested that 'the whole experience [of creating a national memorial] exacerbated the sense that the dead were still not at peace'. ${ }^{29}$ We do know that Weimar officials and elites interpreted the memorial in opposed ways. In the 1931 dedication ceremony, for example, Social Democrat Otto Braun dedicated the 'most Prussian site of all of Prussia' (the Neue Wache) as a site of mourning as well as a national promise to avoid such bloodshed in the future. Germany's generals disagreed with this interpretation and boycotted the opening ceremonies (only three attended); they felt Braun was anti-patriotic, vaterlandlos. The Nazi newspaper mocked Braun and the ceremonies. And the Communist Party (KPD) did not attend because it had just severed the ties with the Social Democrats (SPD). ${ }^{30}$

\section{Commemorating Nazi heros}

With the rise of the National Socialist regime barely two years later, the Neue Wache was transformed to provide a new ritual framework. In 1933 an enormous oak wreath was placed on each side of the pavilion's facade and a large wooden oak cross added to the interior room (Figure 3). Although the physical transformation of the memorial was minimal, the exterior neoclassical structure, together with the addition of the cross, sought to stabilize Hitler's myth of 'the thousand-year Reich'. The placing of the Christian symbol in the interior room transformed the oak wreath and boulder into a secular altar, as the interprestive field of the cross redefined German national icons. The sacred associations of the cross were intended to legitimize Hitler's fiction that the Nazi state was chosen by God as the successor of the Holy Roman Empire. Furthermore, the meanings of Christ's death and resurrection symbolized by the cross were also to be understood according to Nazi ideology. In the Third Reich, a soldier's death was not considered a loss, but rather a necessary act for the renewal and resurrection of the state. Like the Christ-figure, a solider who died serving his people would become immortal through his symbolic resurrection into the body politic of the German Volk. ${ }^{31}$ By selectively combining more general Christian meanings with specific Nazi myths, the new material form of the Neue Wache was intended to define the German people as 'the true Christendom'.

As a sacred space, the Neue Wache became a ritual site of the structured Nazi calendar. In 1931, on its establishment as a war memorial, it was called a Gedächtnisstätte, literally 'a place of remembrance'. Under the National Socialists it was renamed Ehrenmal, or a (Reich) memorial of honour. Thus transformed, the Neue Wache became a place of honour, rather than strictly of commemora- 


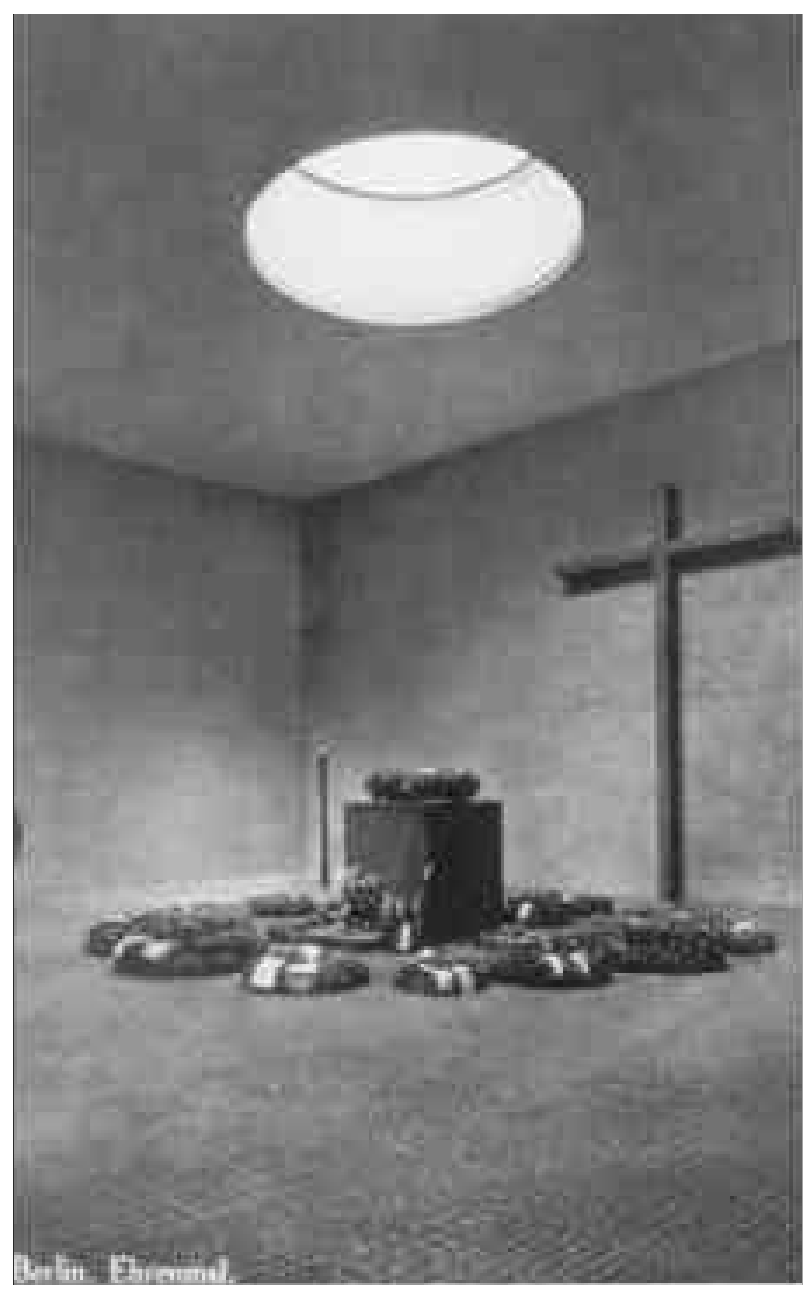

Figure $3 \sim$ The inner room of the Neue Wache after 1933 (photograph reproduced by courtesy of the Deutsches Historisches Museum)

tion and mourning. On 'Hero's Day', Hitler and his dignitaries laid ceremonial wreaths at the Neue Wache and citizens gathered along Unter den Linden to watch the Wehrmacht parade. A military watch, rather than civilian guard, was posted at the memorial under the National Socialists and the popular spectacle of the changing of the guard became a regular tourist attraction.

\section{An anti-fascist site of memoy}

After the Second World War, Berlin's historic district lay within the Soviet occupation zone and later became part of the German Democratic Republic (GDR). Officials of the new East German socialist state rejected the values communicated along Unter den Linden's landscapes, in particular those of Prussian and 


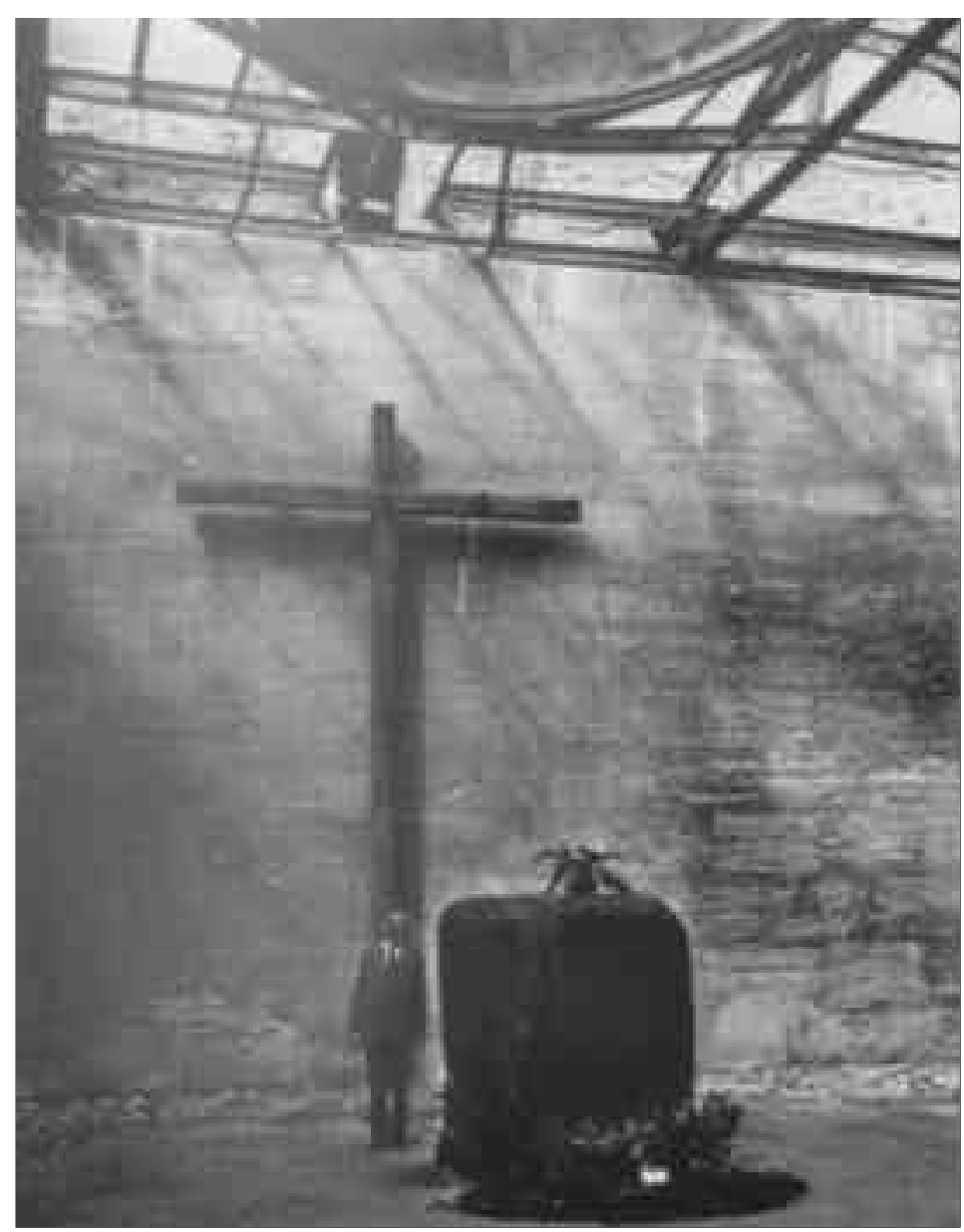

Figure $4 \sim$ The inner room of the Neue Wache following the Second World War (photograph taken by Robert Capa in 1945, reproduced by courtesy of the Cornell Capa)

Nazi imperialism. The Socialist Unity Party (SED) of the GDR altered the spatial organization and morphology of their capital city to reflect new values of international communism. In the late 1950s, the Hohenzollern City Palace was dynamited and replaced with a modernist building that housed the GDR government (called the Palace of the Republic). In 1961, the Brandenburg ('Victory') Gate was sealed off with the construction of the Berlin Wall. The Neue Wache, which had been severely damaged during the war (Figure 4), was repaired in 1951-2 and in 1957 was renovated as a memorial to victims of fascism. The original neoclassical design was used for the exterior and Tessenow's marble block, disfigured by fire, was left as a stark reminder of the destruction of the Nazi regime (the wreath had been stolen in 1948). ${ }^{32}$ The Neue Wache was officially designated a Mahnmal für die Opfer des Faschismus und 
Militarismus, a site of admonishment that communicated the message 'never again!' to German citizens. ${ }^{33}$

During the second part of the Cold War, the Mahnmal, as a type of memorial in the GDR, became associated with the myth of anti-fascism, an official narrative underwriting the socialist party's leadership. It defined East Germany as a state dedicated to fighting fascism in all its forms, from Nazism to capitalism. High-ranking party officials were designated the moral leaders of Germany because of their histories as communist resistance fighters persecuted by Nazis. ${ }^{34}$ The cultural rituals that naturalized anti-fascism were enacted on the hallowed earth where national martyrs suffered and died, that is, at concentration camp sites like Buchenwald. ${ }^{35}$ Thus, in 1969, the twentieth anniversary of the socialist state, the Neue Wache was transformed into a secular altar to anti-fascism (Figure 5). Its interior room was redesigned to include the GDR coat of arms and an eternal flame, under which were buried urns that contained sacred relics: soils from concentration camp sites (Auschwitz, Mauthausen, Natzweiler, Dachau

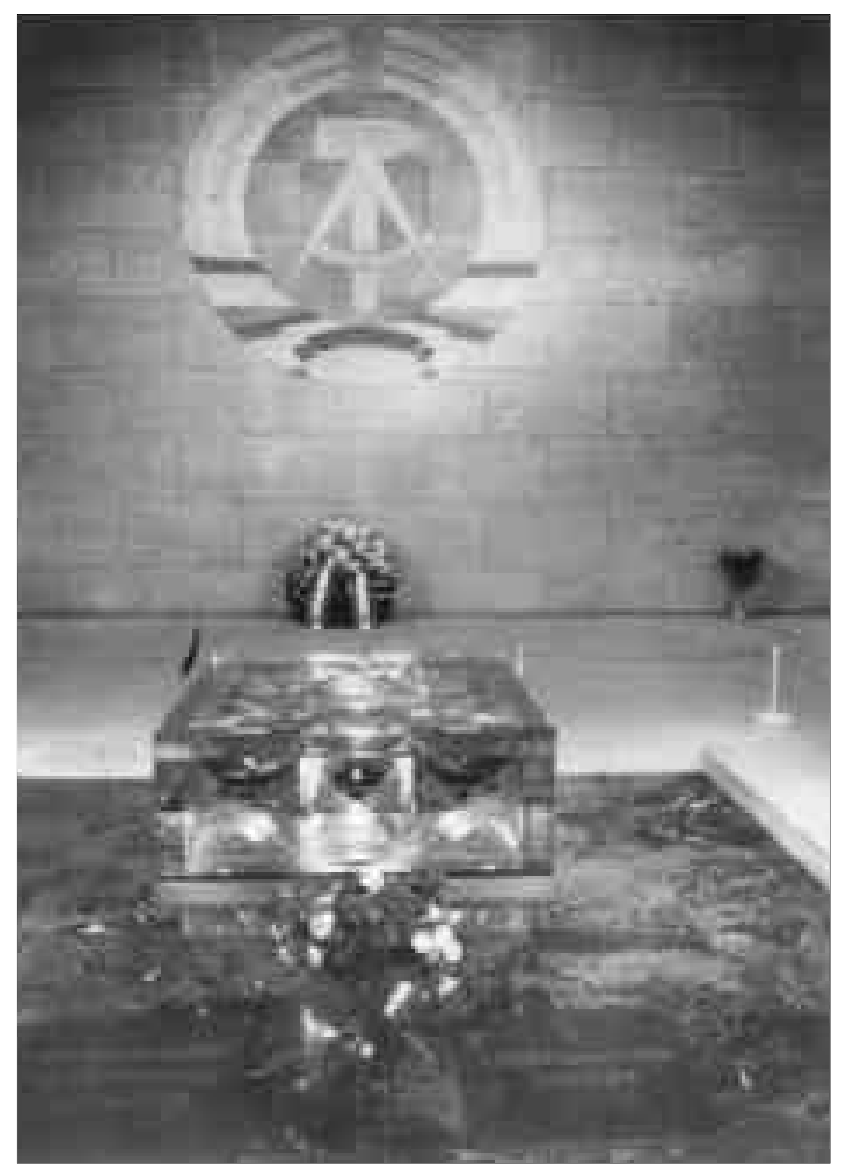

Figure $5 \sim$ The redesigned interior room of the East German memorial, 1969 (photograph reproduced by courtesy of the Landesbildstelle, Berlin) 
and Buchenwald), the remains of an unknown resistance fighter shot during an evacuation march, the remains of one unknown German soldier and soils from battlefields (Moscow, Leningrad, Stalingrad, Normandy, Italy, Norway, Prague and Berlin). ${ }^{36}$ In this form, the memorial functioned as a cemetery bringing together the memory of resistance fighters and the GDR military. The burning flame paid tribute to them, an emblem of the state's continued struggle against fascism. Externally, the image of the Neue Wache was that of goose-stepping soldiers protecting the sacred site, a physical presence suggesting continuity from past to present. A more populist ritual was introduced by the state, as newly wed brides were encouraged to make a pilgrimage along Unter den Linden, from government buildings to the memorial, in order to lay their wedding bouquets before the eternal flame, paying tribute and gaining the blessings of the 'holy' memory of resistance fighters. Such secular rites were a means of legitimating the socialist state in everyday life and counterpoised to conventional Christian ceremonies. ${ }^{37}$

\section{Redesigning the Neue Wache after unification}

A redesigned Neue Wache was ceremoniously unveiled on 14 November 1993 when Chancellor Kohl laid a wreath at the new national memorial (Zentrale Gedenkstätte der Bundesrepublik Deutschland für die Opfer von Krieg und Gewaltherrschaft) ${ }^{38}$ In the words of the plaque to the right of the entrance: 'The new guardhouse is the place of memory and remembrance of the victims of war and tyranny', a central German memorial dedicated to those who died during 'the two World Wars and the two dictatorships'. ${ }^{39}$ The exterior of the structure remains true to Schinkel's original designs (see Figure 2) and the interior room is based upon Tessenow's 1931 granite floor and a circular roof opening. As a gesture to East Germans, the buried urns remain. What is new is the central sculpture in the interior room: a five-times-enlarged copy of Käthe Kollwitz's 1937 statue, 'Mourning mother with dead son' (see Figures 6 and 7).

Following the economic, social and psychological adjustments of unification in 1990, the official attempt to create a traditional ritual space in order to enact a singular German memory and provide continuity between past and present should have come as no surprise. Because Berlin was the place where the ideological competition between the two German states was most dramatically expressed, after unification many East German institutions in the historic district were quickly shut down. Many were viewed as symbols of Germany's division, a direct consequence and thus reminder, of National Socialism. A socialist built environment was considered inappropriate to the new Germany, a democratic nation that had 'won' the Cold War and could now move to a future unencumbered by the remnants of recent pasts. ${ }^{40}$

Although there was widespread support for the memorial, as evidenced by the representatives attending the opening ceremonies, there were also a number of social groups who opposed the rededication of the Neue Wache. Heated debates took place in local and national newspapers, on television talk shows and at local events and actions. These public deliberations about the establishment of the 
new national memorial in Berlin resonated within a longer-standing history of (pre-unification) West German cultural understandings concerning the significance of the National Socialist past in contemporary society.

\section{Negotiating public memory: debates in the media}

If public memory takes place in the cultural arena, then media productions, such as newspaper articles, are places where collective memories are framed, negotiated and entangled. Media's coverage of an event may generate a larger public interest and participation in the establishment, form and interpretation

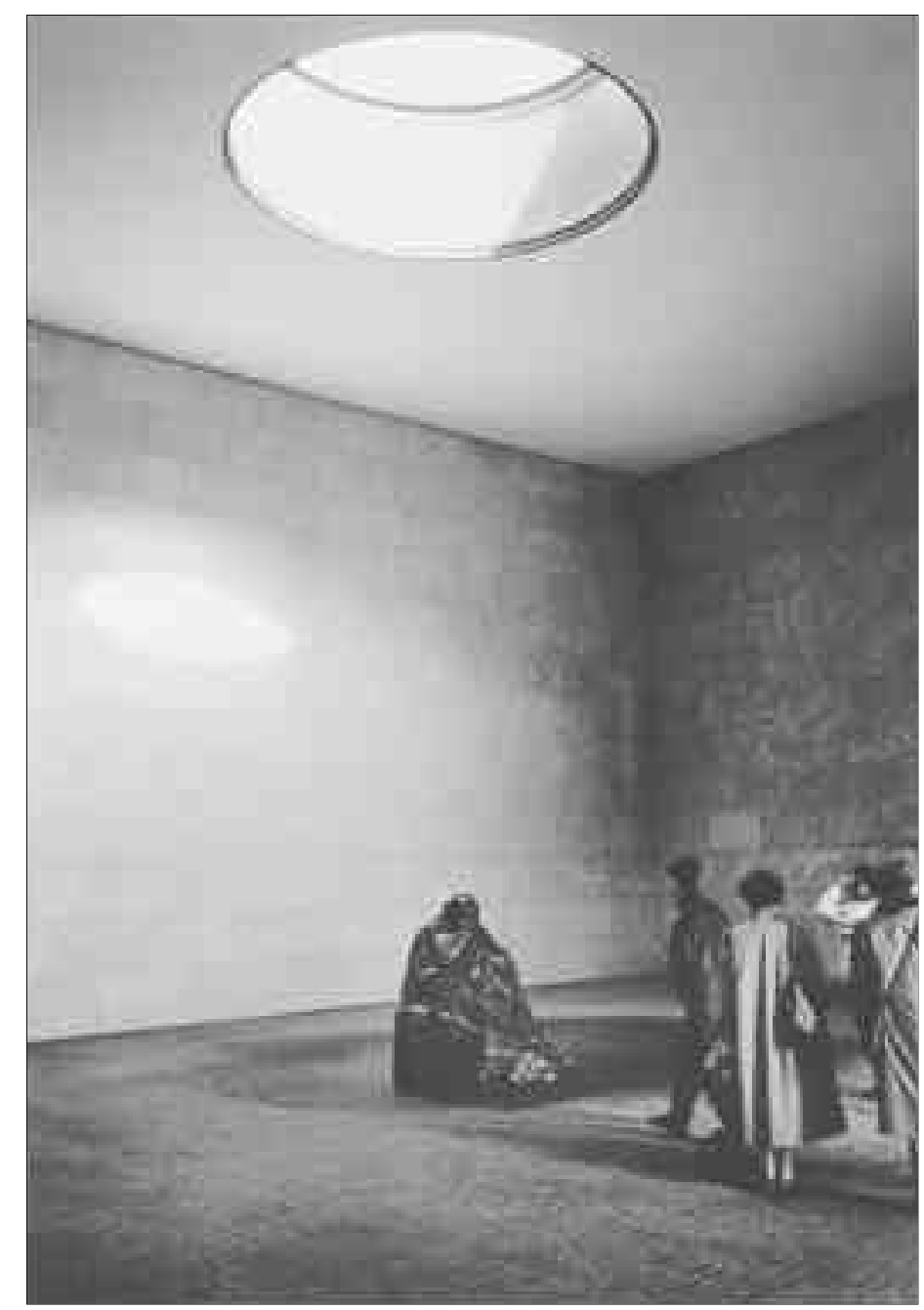

Figure $6 \sim$ The redesigned inner room of the Neue Wache (photograph taken in 1994 by the author) 
of such places as the Neue Wache. At the very least, people may comment on 'the news' in everyday spaces like the home, the neighbourhood bar, day care centres or at the workplace. But even as the media expands the possibility for public discussion, it simultaneously limits the terms of public debate and the voices heard. Notwithstanding the fact that the numerous newspapers in Germany reflect a wide range of political leanings, the search to maximize readership and profits often results in a simplistic rendering of complex topics, the translation of diverse opinions into sound-bite quotes and the use of stereotypes to encourage reader identification.

Through a qualitative content analysis of newspaper articles about the Neue Wache, I identify two ways in which media framed public debates. ${ }^{41}$ First, opinions were privileged according to West German interest group representations. Second, criticisms of the memorial were classified according to established points of contention, some of which made reference to previous media events

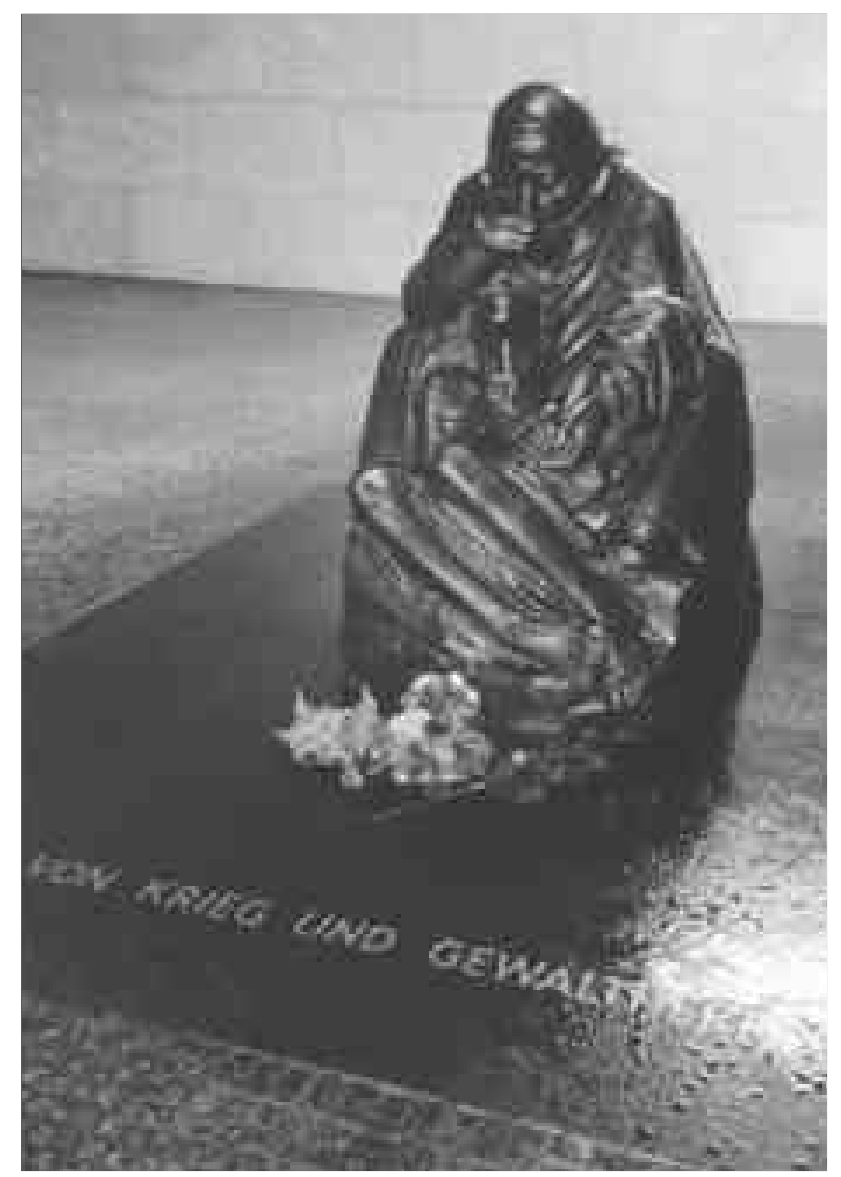

Figure $7 \sim$ The Neue Wache's central sculpture in the interior room, a five-times enlarged Käthe Kollwitz 1937 statue, 'Mourning mother with dead son' (photograph taken in 1994 by the author) 
in the Federal Republic. Before commenting upon these social roles and criticisms, however, I describe the larger social and historical West German framework in which post-unification media debates about the Neue Wache are situated.

\section{The media and Erinnerungspolitik}

Through the media, the memorial came to symbolize (and become enmeshed with) existing public memory disputes about the role of the National Socialist past within contemporary German social relations. Forms of social circumspection are referred to as Vergangenheitsbewältigung, mastering the Nazi past, or Aufarbeitung and Auseinandersetzung (mit) der Vergangenheit, working through or confronting the past. ${ }^{42}$ Taken together, these culturally specific West German concepts refer to a form of 'memory politics' - Erinnerungspolitik - that dates back to at least the mid-to late 1950s about such topics as denazification and publiceducation programmes, annual retribution payments to Israel and the Nuremberg trials. More recent discussions included such events as Willy Brandt's visit to the Warsaw Ghetto Memorial in Poland; the student revolutions in the 1960s; a decade of radical left-wing terrorism and social unrest in the 1970s; scholarly debates, articles and books about the Holocaust, the Second World War and the Third Reich; the production of films and autobiographies about the recent past (both foreign and domestic); and the establishment of public projects like national historical institutions and monuments. The public discussions of the Neue Wache, therefore, constitute the first media event of what this concept meant following unification.

In contrast to this West German tradition of public media debate, East German press reports about the social responsibility for the past were defined by the SED party (often in terms of the anti-fascist myth and as framed by larger Eastern bloc politics). A more 'open' discussion took place behind closed doors (and at personal risk) with family members over kitchen tables or with trusted friends in churches. Therefore, although the media controversies about the Neue Wache occurred in post-unification Berlin, they must be situated within this divided history of public memory that, after unification, continued to be framed by the (West) German media. As a result, the possible opinions of East Germans were not reported by the press because they were not recognized by the media (or perhaps by the reading 'public') as legitimate or authoritative actors. Only when they fitted existing interest group categories (which I discuss below) were these voices represented. In addition, communist societies were not structured by the Western dualism of public/private spheres, but rather by state/family arenas. East Germans therefore may have found it difficult to enter mediadriven 'public' debates, even if they wished to, because they did not have a history of participating in this West German memory tradition. ${ }^{43}$

Another significant aspect of Erinnerungspolitik is the approval process for public institutions, buildings and artwork. In the Federal Republic, before a public project can be authorized by the parliament, a formal competition is carried out. During this lengthy procedure, the media interrogate the social meaning of the institution or artwork, the various proposals submitted and the winning 
submission. Newspaper articles are often considered by politicians in parliamentary debates and by members of quasi-public expert commissions when selecting the winning project. In other words, in (West) Germany a memorial is viewed (at least in theory) as the outcome of a public process of working through the past, not just an official staging or representation of history.

In the case of the Neue Wache, however, no competition or formal hearings took place; the memorial was approved on 27 January 1993 by the Chancellor's cabinet without debate in the federal parliament. Groups with a vested interest in this political process were outraged about what they saw as an undemocratic means of approving the memorial. Without the 'normal' public competition for the memorial, the motives of the federal government were questioned and considered an attempt at Vergangenheitsbewältigung, mastering the Nazi past. Ignatz Bubis, the General Secretary of the Central Council of Jews in Germany, was surprised when he heard that the plans had been passed without the public discussion that he felt was an essential part of defining a memorial in Germany. ${ }^{44}$ Members of the Social Democratic opposition party called for a stop in the transformation of the memorial in 1993 in order to rethink its concept, and spoke on behalf of victim groups: 'Neither the Central Council of Jews nor the Central Council of German Sinti and Roma, neither the Victims of Euthanasia-Politics nor the Persecuted Homosexuals have had to date the chance to discuss the concept with the federal government. ${ }^{45}$ In the words of journalist Mariam Niroumand: 'It is hard to say what is more horrifying: the brutal indifference, the shameless apology, or the ending of a debate from above, a debate that never once began, which would have brought about a social decision about who mourns for whom in whose name.' ${ }^{46}$ Reinhard Koselleck, the most vocal historian in these debates, argued that the lack of a public 'battle' effectively extinguished 50 arduous years of the conflict-laden memory-work in Germany, that is, of working through German experiences, of collectively deciding what the most appropriate form of commemoration should be and of continuing historical research about the Nazi period. ${ }^{47}$

As these quotes indicate, discussions about memorials are part of a collective negotiation, an Erinnerungspolitik defined by particular social roles and processes. I now turn to the interest groups that have been given a voice in these West German media debates, before describing the main points of contention concerning the Neue Wache.

\section{Interest groups in West German public memory debates}

Analysing the newspaper articles about the memorial, I identify at least four interest groups that were delineated in the press and that resonated within the cultural history of West German Erinnerungspolitik. First, and most importantly, groups were defined by their political party affiliation. Although Germany has a multi-party system, the media often present political opinions as either supporting or opposing the current party or coalition in power. In 1993, the Christian Democratic Union (CDU/CSU) was in office at city-state and national levels, while the Social Democratic Party (SPD) was in opposition. The other 
major party, the liberal Free Democratic Party (FDP) (which has been struggling to define a post-unification identity), is often in a coalition with the party in power (in this case the CDU). A fourth, more recent, national-level party, the Greens, defines a distinct platform from the two main parties, but has at times worked with the SPD. Following unification, the party allied itself with a new eastern party to become Alliance '90/the Greens. The Party of Democratic Socialism (PDS) is a new national party based upon the former East German Socialist Unity Party (SED) (the central ruling communist party of the GDR) and is supported by a large East German constituency. It is through the PDS that East Germans were offered a voice in the debates, although they were treated with suspicion because of the party's history. Finally, at local levels, a number of smaller, protest or alternative parties have formed since unification (and earlier in West Berlin). ${ }^{48}$ For the Neue Wache dedication ceremonies, representatives from the three major parties (CDU, SPD and FDP) appeared, denoting some consensus of approval for the memorial. Members of the Alliance '90/the Greens and the PDS explicitly did not attend, and some members of the SPD also boycotted the ceremonies.

A second category that is important for understanding these discussions is the so-called 'victim groups' in German society. Socially constructed as the opposite of 'perpetrators', these groups represent the peoples who were systematically persecuted and murdered by National Socialists; they all have international affiliations. These groups were not as involved in the Neue Wache discussions as one might expect, largely because of the simultaneous debate over the establishment of a central Holocaust Memorial in Berlin. For the case of the Neue Wache, the national spokesperson for the Central Council of Jews, Ignatz Bubis (associated with the FDP), was critical of the memorial in the early part of the discussions but ultimately agreed to a compromise solution (which I discuss below) and attended the wreath-laying ceremony with Chancellor Kohl. ${ }^{49}$ Representatives of the Central Council of Sinti and Roma were also present for dedication ceremonies. The Berlin Jewish community, however, did not attend, nor did the Association of Political Persecutees of the Nazi Regime (VVN).$^{50}$ Groups representing victims, such as those persecuted under Stalinism and communism, approved the memorial.

Well-educated professionals, including academic historians, local historians, artists, art historians, historic preservationists, museum experts, memorial centre educators and directors and a select group of publicists and journalists constituted a third group involved in public memory discussions. The opinions of such experts are normally respected in German society; historians, in particular, are seen as the moral voice of the nation and often write articles about cultural identity and collective responsibility for the National Socialist past. Through the media, academics may gain public respect and sometimes even scholarly notoriety, as evidenced in the long-standing 'Historians' Debate' of the mid-1980s when the sociologist Jürgen Habermas attacked the respected German historians Ernst Nolte and Andreas Hillgruber for writing revisionist histories. ${ }^{51}$ In the Neue Wache discussions, the social historian Reinhard Koselleck had a prominent voice and remains critical of the memorial. Artists and art 
historians from Berlin's Academy of Art also participated in the debates, but were given less prominence in the media.

A fourth category - and for the Neue Wache debates, one that is associated with the reputation of political radicalism in Berlin and was reported on mostly by the local press - includes citizen initiatives and alternative groups. Individual members that do get media attention are often scholars or professionals, and as a result the national media interpret them as belonging to the third group rather than representing a local perspective. The national press also associates these groups with opposition or alternative parties. For the Neue Wache debates, the local citizen initiative, the Active Museum for Resistance to Fascism in Berlin (Aktives Museum Faschismus und Widerstand in Berlin, e.V., hereafter Active Museum), organized many protest activities. The national Protestant youth organization, Aktion Sühnezeichen/Friedensdienste, was also critical of the memorial.

In general, these four overlapping interest group representations can be seen as familiar characters engaged in West German controversies about social responsibility and the National Socialist past. With this in mind, I turn to a discussion of the main types of argument surrounding the Neue Wache.

\section{Three points of contention}

As expressed in newspaper articles, the logic of most criticisms could be classified according to one of the following three overlapping arguments: (1) the function of the memorial as a public institution; (2) the form of the memorial; and (3) which dead should be commemorated. ${ }^{52}$ The most serious official challenge (albeit as distilled by the media) related to the last concern: namely, how victims and perpetrators should be remembered in Germany.

The national memorial as a type of place. A common theme that emerged in discussions was a concern about the function of a traditional memorial in presentday Germany. The very existence of a national place of memory was considered an inappropriate type of place in German society, especially when bearing in mind the legacy of National Socialism, as evidenced by post-unification neo-Nazi activity and xenophobic acts of violence (particularly apparent in 1992-93 during these media debates). Citing the history of the Neue Wache during the Nazi and GDR periods, critics argued that no memorial or landscape should function again as a stage for nationalistic ritual. The very concept of a central public institution, they argued, raised this ugly heritage of nationalism and challenged Germany's postwar democratic history of federalism.

Implicit in this concern about centralized, national institutions is a sense of social unease about the historical uses and functions of the capital city as a symbol of the nation and a related larger critique of the cultural politics of the CDU since the early 1980s. ${ }^{53}$ Indeed, the establishment of a system of strong local and state-level autonomy in West Germany was a direct response to the centralized National Socialist state (most dramatically expressed in Berlin's landscapes) and to Allied, in particular American, denazification programmes. In more recent years, critics of the CDU were quite concerned with Kohl's attempts at nation-

Ecumene 19996 (3) 
building, especially regarding his proposals to establish national history museums in Bonn and Berlin and a war memorial in Bonn. ${ }^{54}$ When asked in 1985 why he supported the construction of the war memorial, Kohl responded that every national capital in the world - with the exception of West Germany - had a place where dignitaries could lay their wreaths on official occasions in an appropriate manner. ${ }^{55}$ Such a response did not sit well with critics of the CDU administration, who are wary of what they describe as Kohl's 'pet projects,' that is, cultural institutions imposed from above rather than emerging from state or local levels. The Neue Wache was viewed as such a project by many groups because of the way it was approved without the normal public competition process.

The Neue Wache, moreover, when considered as one project among other proposed traditional, national places, can be understood within the context of the administration's pre-unification political agenda, what I call the 'cultural politics of normalization'. ${ }^{56}$ Although the goal to create a 'normal' nation after National Socialism has been part of the official German policy since the time of Konrad Adenauer, under Kohl normalization came to mean that Germany should be simultaneously defined as a cultural nation and a European political state. The former notion implies Western ideas of individual freedom and national self-determination and the latter demands surrendering certain sovereign rights to such supranational organizations as the EU and NATO. Under the Kohl administration, Willy Brandt's notion of normal relations between the Eastern and Western blocs were continued, but at the same time a neoAdenauerian notion of shared Western values was promoted. Since the mid1980 s, these values meant not only the promise of unification but also the freedom to define national sovereignty without being viewed with suspicion by other Western countries. In the cultural realm, this included, to use Michael Stürmer's words (a conservative historian and former political adviser of Kohl), the renewal of national self-confidence by providing positive images of the past: 'In a land without history, whoever fills memory, coins the concepts and interprets the past, wins the future. ${ }^{57}$

After 1990, normalization as a strategy appears to have expanded somewhat to include defining what it means to be 'European', a cultural form of identification that resonated with Kohl's political and economic agenda to strengthen Germany's role in the European Union. Current proposals for the reconstruction of Berlin's historic district, of which the Neue Wache is part, favour 'typical' (yet vague) European landscape images of 'appropriate' royal, pre-national pasts. ${ }^{58}$ For example, the Hohenzollern City Palace, which was completely demolished by the GDR in the 1950s is now under consideration for reconstruction by German businessmen as a private initiative. In 1993, a trompe-l'œil of the fourstorey historic palace was erected across from the 'Museum Island' in MarxEngels-Platz to give Berliners an idea of how a new Unter den Linden landscape might look, and to find sponsors for the project. ${ }^{59}$ The Brandenburg Gate has reopened and the copper quadriga was refurbished to its pre-GDR image: the goddess Nike's staff is based upon Schinkel's designs (used from 1814-1945) with an Iron Cross within a wreath, on top of which sits a Prussian eagle. ${ }^{60}$ 
Schinkel's designs for Unter den Linden have become fashionable, as demonstrated by the renovation of historic buildings in the 'Museum Island', including the baroque Zeughaus, Schinkel's masterpiece, the Altes Museum, and buildings designed by his student Friedrich August Stüler, the Neues Museum and the Nationalgalerie. Quasi-public tours bring Berlin's visitors to the '350 years of history' along Unter den Linden; historic maps, photographs, sketches and newspaper articles are used in conjunction with existing buildings, ruins, or empty sites to stir a tourist's imagination of this more grandiose past.

Such a romanticized image of Berlin, projected alongside high-tech representations of futuristic new business complexes, is promoted by businessmen as well as by officials. The pre-national is a safe and seemingly uncontested period to recreate when presented as an European rather than purely Prussian heritage; it is based upon nostalgic landscape icons and highly stylized histories that attract tourist dollars and provide a sense of pride in the past. It is a familiar time/space to create during a period of unprecedented change. Not surprisingly, the politics and meaning of such reconstructions have been called into question by social groups critical of normalization politics. Other critics view these historic projects as unnecessary luxuries in a city where unemployment is high, infrastructure inadequate, and available housing units are scarce.

The form of the memorial. Another principal point of contention was the form of the memorial. Art professionals and historians were concerned with the exclusive religious message of the statue. The Kollwitz sculpture was seen as embodying a particularly Christian form of suffering and thus of German identity. The statue of the mother holding her dead son, argued many, was a version of the Pietà, a Christian icon symbolizing salvation through Christ's death (Figure 7). How could Jews, for example, be asked to honour their dead through such a symbol? The sculpture, when interpreted as a Pietà, identified Germans as nonJews and thereby excluded the memory of the latter. To counter these criticisms, supporters of the memorial argued that the Kollwitz sculpture represented a more universal, non-divisive message of loss. From this perspective, the figure of a mourning mother could be understood by all social groups in German society, including Jews. ${ }^{61}$

The gender-biased depiction of this 'universal' mother, however, was almost ignored in national media discussions, and was voiced at the local level through alternative artists' and citizens' initiatives and through related publications that I discuss below. ${ }^{62}$ Yet in the cultural context of a traditional memorial monument, the sculpture clearly depicts women as passive mothers, mourning the loss of sons and husbands whose role it is to protect the nation from external threat. Such an idealization of motherhood naturalizes the spheres of the public and private as masculine and feminine respectively, defining women's sexualities and social roles exclusively in terms of reproduction. The historian Koselleck argued that the Pietà figure closed out the public memory not only of Jews, but of women who were sent to the gas chambers or who died in other ways during the war. Women, argued Koselleck, were not victims simply because they lost 
their sons - 'the reality was far worse'. ${ }^{63}$ Although Koselleck's criticism was an attempt to break the traditional private/public dichotomy associated with national representations, he still suggested that women should be thought of as victims of some sort. Thus, in the media debates, women were not defined as socially relevant actors, let alone considered as perpetrators. ${ }^{64}$

Why were the histories of women during the wars and postwar period silenced in the national public debates? Why did an exclusively heterosexual symbol of the nation remain uncontested in 1993? Although this subject is beyond the scope of this paper, I raise it here to indicate that topics excluded from public debates are pertinent to the formation of cultural identity at a transitional period of time. I offer two speculative (and disturbing) suggestions that relate to concerns of national security. First, German unemployment rates rocketed after 1990 and have remained high, particularly for middle-aged men and women in the East. If women are located 'at home', competition for scare jobs could be reduced, at least in appearance. Such an image, of course, would be particularly jarring for East German women, who had the highest participation in the workforce in the world in the late 1980 s at $91 \%$, but now constitute $60 \%$ of the unemployed. ${ }^{65}$ Secondly, following unification, there was a general fear that Germany was becoming inundated with foreigners. ${ }^{66}$ In the late 1980s, (West) Germans were facing projections that people of 'Germanic' descent would no longer be the majority ethnic-racial group in the future due to low birth rates. Such anxieties were exaggerated following 1990, as Germany experienced an influx of Eastern European and former Soviet Union refugees resulting from civil wars and the collapse of the Eastern bloc. Imagining German women in 'natural' terms - as mothers rather than as citizens and workers - was a culturally conservative strategy used historically in Germany and elsewhere to offset fears of 'foreign invasion'.

A second concern was also articulated about inappropriate uses of aesthetic and historical forms for the Neue Wache. Historic preservationists, for example, argued that the proposed designs were inauthentic. Although documentary evidence could have justified renovation to any historical style, the proposed design was considered a pastiche of architectonic forms and elements from diverse historical periods. Most preservationists argued that reconstructing the pavilion to its 1931 form, when it was first used as a memorial, would be most appropriate and historically accurate. Supporters of the proposed memorial, however, did not view the memorial as an historic artefact to be preserved and renovated, but rather as a contemporary site of commemoration marked by traces from each phase of German history.

These media concerns about the form and function of the memorial did not appear to have a direct impact on official plans. Despite protests at federal and local levels and the results of an expert hearing (which voted 3-2 against the memorial), no alternative forms of commemoration were considered. I turn finally to the third main point of contention, which, when taken together with the first two points, did result in a small material change in the memorial design. 
Commemorating the dead. The third main criticism of the Neue Wache was the 'forgetfulness' of the memorial. Of particular concern was the way that it recalled the dead. Critics argued that by commemorating all the war dead at one location, the Neue Wache blurred the social boundaries between those persecuted and murdered under the Third Reich on the one hand and the SS officers and high-ranking Nazi functionaries on the other. In other words, the postwar categories of social identity between victims and perpetrators would be collapsed at the site. From this perspective, creating a central place of commemoration for all war dead would mean that all individuals would be made equal through the category of death. In this way, argued critics, the dead would be neither commemorated nor honoured: 'the dead deserve our attention and respect, the SS officers don't belong to that group. ${ }^{67}$

By suggesting that the memorial was forgetful, critics alluded to previous public memory debates in which the Kohl administration was criticized for attempting to master the past and to represent all Germans as victims of war. Such media discussions included at least three controversial events. I have already mentioned the proposal to establish a central memorial in Bonn that would 'unite victims and the sacrificed in reconciliatory commemoration' and the museums established in Bonn and Berlin that were accused of promoting revisionist, nationalistic histories. A second event, also mentioned above, was the ongoing 'Historians' Debate' in which scholars fought about the politics of writing histories and of using certain methods to represent the National Socialist period. ${ }^{68}$ The third event is referred to as the 'Bitburg Affair'. As part of the commemorative activities for the 40th anniversary of the end of the Second World War, Chancellor Kohl and President Reagan made a ceremonial visit to the military cemetery in Bitburg, a place where 49 members of the Waffen SS (combat stormtroopers) were buried alongside First and Second World War German infantry soldiers and Wehrmacht officers. Describing this event, Anson Rabinbach quoted Kohl to define official CDU reconciliation, 'when we are able to mourn for human beings, independent of whatever nationality the murdered, the fallen, the dead once belonged'. ${ }^{69}$ Rabinbach argued that by staging this notion of reconciliation in the media, the Kohl administration was the first publicly to relativize the Holocaust in relation to all other sufferings inflicted by the war. The historian Charles Maier has defined this use of the past as 'Bitburg history', the mixing together of historical agents and moral categories that results in the distortion of the logical dependence of victim and perpetrator and therefore a shared responsibility for wrongs committed. ${ }^{70}$

To ensure that 'all dead would be remembered, not just "our" dead', the historian Koselleck simply suggested adding an inscription to the memorial's entrance that would read: 'In memory of those fallen, murdered, gassed, killed, missing. ${ }^{\text {71 }}$ Although some journalists derided this 'shopping-list' approach to commemoration, Koselleck's proposal was generally accepted. Once the proposal was put forth in the public arena, Ignatz Bubis, for one, demanded that such a text be added to the memorial.

In the context of the media debates about the Neue Wache and, perhaps 
more importantly, in response to a much larger history of discussions about mastering the past, or Vergangenheitsbewältigung - officials decided belatedly to add a modified passage from a 1985 speech by former German President Richard von Weizsäcker. This speech (delivered months after the 'Bitburg Affair' and seen by some as a reprimand to the Kohl administration) was the first public occasion on which a German official clearly acknowledged differences between the social groups that suffered during the Second World War. The passage added to the Neue Wache was inscribed on a bronze plaque to the right of the entrance to the interior room. It has been translated into eight languages, and reads: ${ }^{72}$

We honour the memory of the peoples who suffered from the war.

We remember their citizens who were persecuted and who lost their lives.

We remember those killed in action in the World Wars.

We remember the innocent who lost their lives in war and as a result of war in their homeland, in captivity and through expulsion.

We remember the millions of Jews who were murdered.

We remember the Sinti and Roma who were murdered.

We remember all those who were killed because of their origin, their homosexuality or because of sickness and weakness.

We remember all who were murdered, whose right to life was denied.

We remember the people who had to die because of their religious or political convictions.

We remember all those who were victims of tyranny and met their death, though innocent.

We remember the women and men who sacrificed their lives in resistance to despotic rule.

We honour all who suffered death rather than act against their conscience.

We honour the memory of the women and men who were persecuted and murdered because they resisted totalitarian dictatorship after 1945 .

According to Marcuse, although this text is a weaker version of von Weizsäcker's 1985 speech, it was a significant compromise for officials publicly and in a permanent material form, to recognize the distinctions between different social groups, especially when considering the history of Kohl's cultural politics of normalization. It may also become the new touchstone for future public memory debates in Germany, the most notable of which are the ongoing Holocaust Memorial debates. ${ }^{73}$

\section{Local memory: alternative cultural realms}

Although the media was the dominant arena in which interpretations of the past were negotiated, citizen initiatives and Berlin groups actively engaged in the process of public memory locally by hosting cultural events. These can be viewed as a means of group legitimation through rejection of official interpretations and the realm of the media. They should also be seen as attempts to create a 
more inclusive, local public discussion and to provide a space for excluded groups.

For example, artists and art historians, many of them women, felt that their criticisms were not considered by officials. In national media debates, they argued that enlarging the Kollwitz sculpture at the Neue Wache was an abuse of artistic licence. Critics stated that the statue was never intended for such a memorial; since Kollwitz created the sculpture in 1937, she would have been unable to articulate the horror of the Holocaust. ${ }^{74}$ Taking her artwork out of that historical context and enlarging it five times as a memorial was artistically inadmissible. To pay tribute to Kollwitz, the Academy of Arts in Berlin and other related organizations conducted a series of public lectures and exhibitions about the artist, her work and her pacifist politics and published a book about the Neue Wache debates. ${ }^{75}$ These cultural products expanded the terrain of public memory debates beyond the traditional limits of the media. Moreover, the creation of a popular forum for participation and learning was a way of reclaiming interpretive rights over art. Drawing from the history of the artistic community in Berlin, recognized for its progressive politics, these groups created a space for an interested public to confront the relationships between an art, memorials, public space and German identity.

Alternative memorial designs were also envisioned as oppositional spaces challenging traditional realms of historical authority. Particularly interesting was one by the Berlin citizen initiative, the Active Museum. This group advocated leaving the memorial in its East German form and treating the structure as an historical artefact. Instead of creating a new monument, they wished to deconstruct the past in situ and thereby create a non-traditional outdoor living museum. They suggested erecting a system of signboards at different points in and around the memorial to provide historical information about its physical transformations under the different Germanies. Through this exhibition, the uses of the Neue Wache by various government officials would be presented, and the continuities between past and present narratives of the nation would be critically addressed.

Such an alternative questions the past and present functions of the Neue Wache. In this traditional place of memory created by male elites, the dead have symbolized the nation through conventional religious and gendered categories. In contrast, the citizen initiative's approach introduced a postmodernism of resistance in challenging both an object (the national memorial) and the social contexts within which that object has traditionally been constructed and interpreted. ${ }^{76}$ Rather than 'normalize', or even avoid, the uncomfortable category of the 'nation', the proposed outdoor exhibition is a critical reassessment of places of memory in Germany. Indeed, an individual walking onto the site would be encouraged to construct a personal relationship to the nation(s) through an interpretation of texts, photographs and material landscapes. Moreover, the experience of confronting an inverted traditional ritual space, by placing an exhibit outside a public memorial familiar through commemorative ritual, may have led a visitor to reconsider socially expected experiences at sites of memory in the city.

Ecumene 19996 (3) 
The Active Museum's innovative and self-critical challenge to the history of landscape and memory in Germany was not officially recognized. In protest, the group organized a three-month-long exhibition with eleven historical placards (including the contemporary debates) that opened days before the memorial dedication ceremony at the former East German Humboldt University, located next to the Neue Wache (see Figure 1). They also published an accompanying exhibition book with articles about the history of the memorial and critical essays about its new design. Located so close to the memorial, this unofficial event paralleled official events and attracted visitors going to see the Neue Wache (who may have been unaware of the controversies).

\section{Outcomes of public memory: the meanings of the Neue Wache today}

One can interpret the Neue Wache simply as a ceremonial stage upon which officials will continue to perform rituals of nationalism and communicate notions of collective identity. But such a reading would be limiting and superficial, ignoring other actors who have created meaning at the memorial. In 1993, for example, when Kohl and other dignitaries travelled from Bonn to lay the ceremonial wreath at the Neue Wache, many other individuals made journeys. Neo-Nazis made pilgrimages to war cemeteries where well-known Nazi functionaries were buried, local citizen groups conducted protest marches throughout the streets of Berlin, a sizeable police force was at the Neue Wache, and an irate Holocaust survivor was arrested for demonstrating against the memorial. The debates, compromise inscription, alternative proposals and exhibitions suggest that Berliners recognize the selective nature and inherent contradictions of public memory work and engage in this process to an unusual degree. Local groups in particular seem quite aware of the fact that public "memory as a form of knowledge is also a form of resistance'. ${ }^{77}$

Public sites of memory like the Neue Wache gain their meanings through the interplay of historical narratives, official cultural politics, local interests, media representations, expected interest group representations and cultural productions. Here I have focused on how these agents, institutions and objects have been framed by the West German media and expressed in other cultural realms. Two concrete results of this process/site of public memory include the addition of the compromise plaque. Although the text continues to be criticized as missing 'the most taboo elements that electrified the nation in 1985: putting the Jews first, mentioning the Soviets' victims, using the word unsäglich, or unspeakable', there appears to be a kind of acceptance of the compromise. The American historian Harold Marcuse, who wrote these critical words, does not regard the Neue Wache as the site where Holocaust victims should be commemorated. Rather, he views the place as a monument that depicts German's emotional relationships to the Nazi past, those of sadness and regret. ${ }^{78}$

The compromise text may be also accepted as part of a larger history of German Erinnerungspolitik, a set of troublesome and ongoing discussions about 
the meanings (and moral responsibilities) of the social categories of victim and perpetrator. The controversies surrounding a 1996 historical exhibition in Munich about the role of the Wehrmacht in the Holocaust, or the 1997 national public stir created by Daniel Goldhagen's book, Hitler's Willing Executioners, which argued that the Holocaust was the result of a culturally specific German eliminationist anti-Semitism, or the ongoing debates about the national Holocaust Memorial tell us that the Germans are still working through their troubled past eight years after unification and will continue to do so. Nonetheless, as the Neue Wache debates have made clear, these discussions are still largely informed by a West German cultural hegemony. What is more difficult to discern is how the presence of East Germans and other marginalized groups will alter this established social framework of public memory in the future. How, for example, will the first post-unification generation of Germans view, experience, interpret and reappropriate the past and imagine their future at public sites like the Neue Wache?

A second consequence of the Neue Wache debates is more subtle and local. Although the Active Museum and the Academy of Arts staged only temporary activities, their approach reached many who may otherwise have been excluded from national debates. They may also have inspired some to use the site as an alternative space of discussion. For example, on a number of occasions when observing visitors to the Neue Wache in both 1994 and 1997, I noticed local tour groups stopping there. Tour guides brought with them portable exhibitions, so to speak, to display historic photos, copies of documents and newspaper articles, providing critical interpretations that resembled in form and content alternative events. Discussions about the meanings of the memorial thus continue to take place in non-traditional forms. A personal story is revealing: as a guest lecturer for an American university historic preservation programme in 1997, I provided a brief overview of the Neue Wache in the interior room. Unlike the tour guides with props, I used the actual spaces of the interior room to describe the changing historical forms of the pavilion; as I gestured to different parts of the room, my voice echoed loudly against the thick walls. When students asked about my own opinions of the memorial, I offered some criticisms (in a softer tone). A memorial guard, perhaps in response to complaints by other visitors, quickly moved to escort my group outdoors. He claimed that I was being disrespectful to the memory of the dead; we were 'out of place'.${ }^{79}$ For the rest of the day, the group kept returning to this encounter and the material spaces of the memorial, wondering whose dead he meant and trying to unpack a much larger set of meanings about cultural identity and memory in a new Germany.

\section{Acknowledgements}

Earlier versions of this paper were presented at the 'Remembering for the Future II' conference in Berlin in 1994 and at the annual Association of American Geographers conference in Fort Worth, Texas in 1997. Special thanks to Ries Roowaan, Denis Cosgrove, Helga Leitner, Tom Lekan, Rudy Koshar, Heike Alberts, Steven Hoelscher, Miles Richardson, Jim Duncan, Yi-Fu Tuan and an anonymous reviewer for providing helpful comments. Thanks also to the 
Berliners who spoke with me about the memorial, as well as Max Page and students from Georgia State University. Other individuals and organizations that helped with this project include: Mary Lee Eggert at Louisiana State University for producing the map; the Aktives Museum Faschismus und Widerstand Berlin, e.V., the Deutsches Historisches Museum, and the Alexander von Humboldt Foundation, which provided financial support during the time of this study.

Department of Geography

University of Minnesota

\section{Notes}

${ }^{1}$ Quoted in P. R. Range, 'Reinventing Berlin', National Geographic (Dec. 1996), p. 104. Stimann was director of Berlin's department of building from 1992 to 1993.

${ }^{2}$ Berlin, of course, was represented as the centre of Europe before the Wall fell, but for Cold War geopolitical reasons. See S. Campbell, Cold War metropolis: the fall and rebirth of Berlin as a world city (Minneapolis, University of Minnesota Press, forthcoming); and T. Garton Ash, In Europe's name (New York, Vintage, 1993).

${ }^{3}$ N. Johnson, 'Cast in stone: monuments, geography, and nationalism', Environment and Planning D: Society and Space 13 (1995), pp. 51-65. See also A. Charlesworth, 'Contesting places of memory: the case of Auschwitz', Environment and Planning D: Society and Space 12 (1994), pp. 579-93; R. Koshar, Germany's transient pasts: preservation and national memory in the twentieth century (Chapel Hill and London, University of North Carolina Press, 1998); C. W. J. Withers, 'Place, memory, monument: memorializing the past in contemporary highland Scotland', Ecumene 3 (1996), pp. 325-44; and K. Till, 'Place and the politics of memory: a geo-ethnography of museums and memorials in Berlin' (PhD thesis, Dept of Geography, University of MadisonWisconsin, 1996).

${ }^{4}$ D. Dodds and P. Allen-Thompson, eds, The Wall in my backyard: East German women in transition (Amherst, University of Massachusetts Press, 1994). See also J. Borneman, After the Wall: East meets West in the new Berlin (New York, Basic Books, 1991), and H. G. De Soto, '(Re)inventing Berlin: dialectics of power, symbols and pasts, 1990-1995', City and Society 1 (1996), pp. 29-49.

${ }^{5}$ In addition to works previously cited, there is a large literature about landscape and metaphor, and landscape as nationalist spectacle. See D. Cosgrove, Social formation and symbolic landscape (London, Croom Helm, 1984); S. J. Daniels, Fields of vision: landscape imagery and national identity in England and the United States (Oxford, Polity Press, 1993); J. Duncan and N. Duncan, '(Re)reading the landscape', Environment and Planning D: Society and Space 6 (1988), pp. 117-126; R. Handler, Nationalism and the politics of culture in Quebec (Madison, University of Wisconsin Press, 1988); S. Schama, Landscape and memory (London, HarperCollins, 1995). For a discussion of 'narrating the nation', see H. Bhabha, ed., Nation and narration (New York, Routledge, 1990); and G. Eley and R. G. Suny, Becoming national: a reader (New York, Oxford University Press, 1996).

${ }^{6}$ M. C. Boyer, The city of collective memory: its historical imagery and architectural entertainments (Cambridge, MA, MIT Press, 1994), p. 321.

${ }^{7}$ R. Foster, 'Making national cultures in the global ecumene', Annual Review of Anthropology 20 (1991), pp. 235-60.

${ }^{8}$ See e.g. D. Hayden, The power of place: urban landscapes as public history (Cambridge, MA, MIT Press, 1995); and J. Young, The texture of memory: holocaust memorials and 
meaning (New Haven, CT Yale University Press, 1993).

${ }^{9}$ M. Sturken, Tangled memories: the Vietnam War, the AIDS epidemic, and the politics of remembering (Berkeley, University of California Press, 1997). See also J. Bodnar, Re-making America: public memory, commemoration and patriotism in the twentieth century (Princeton, NJ, Princeton University Press, 1992); M Foucault, Power/knowledge, ed. C. Gordon, trans. C. Gordon, L. Marshall, J. Mepham, and K. Soper (New York, Pantheon, 1980); and M. Foucault, 'Film and popular memory: an interview with Michel Foucault', trans. M. Jordan, Radical Philosophy 11 (1975), pp. 24-9.

10 Sturken, Tangled memories.

${ }^{11} \mathrm{~J}$. Webber, 'The relics of Auschwitz', keynote address at the Cultural Studies Institute symposium of the same title (Essen, Germany, Apr., 1993); 'The future of Auschwitz: some personal reflections' (Oxford, Centre for Postgraduate Hebrew Studies, 1992). See also E. Casey, Remembering: a phenomenological study (Bloomington, Indiana University Press, 1987); P. Connerton, How societies remember (Cambridge, Cambridge University Press, 1989); M. Halbwachs, On collective memory, ed., trans. and with introduction by L. Coser (Chicago, University of Chicago Press, 1992; first published in French 1941); D. Lowenthal, The past is a foreign country (Cambridge, Cambridge University Press, 1985); and P. Nora, 'Between memory and history: les lieux de mémoire', Representations 26 (1989), pp. 7-25.

12 According to the French sociologist Maurice Halbwachs, individuals acquire, recall, recognize and localize their memories in social and spatial contexts. To recall an event, we locate ourselves in a particular social-spatial context or framework, depending upon our social identities and needs in the present. Thus, argues Halbwachs, an individual's memory is not simply a set of images coming from a person's unconscious, but is always reconstructed in the social environments of the present. Halbwachs implies that a single person may have multiple memories of the same event, since individuals identify with more than one social group. See Halbwachs, $O n$ collective memory. For a more critical reading of Halbwachs, see Withers, 'Place, memory, monument'.

13 Halbwachs, On collective memory, p. 204.

${ }^{14}$ S. Daniels, 'Marxism, culture, and the duplicity of landscape', in R. Peet and N. Thrift, eds, New models in geography: the political-economy perspective (London, Unwin Hyman, 1989); Halbwachs, On collective memory; and D. Lowenthal, The past is a foreign country.

15 Sturken, Tangled memories, p. 3.

16 There has been some disagreement about the relationship between history and collective memory. Nora, for example, suggests they are opposites, whereas Lowenthal sees the two as part of a continuum rather than oppositional categories. Sturken too argues that cultural memory, while distinct from history, is essential to the construction of history and therefore not its opposite. See Lowenthal, The past is a foreign country and Possessed by the past: the heritage crusade and the spoils of history (New York, Free Press, 1991); Nora, 'Between memory and history'; Sturken, Tangled memories.

17 P. Jackson, Maps of meaning: an introduction to cultural geography (London, Unwin Hyman, 1989), p. 2. See also Sturken, who argues that 'cultural memory is a field of cultural negotiation through which different stories vie for a place in history' (Tangled memories, p. 1).

18 For a more detailed overview of the history of the Neue Wache, see D. Büchten, 'Hundert Jahre im Dienst der Krone', in D. Büchten and A. Frey, eds, Im Irrgarten deutscher Geschichte: Die Neue Wache 1818-1993 (Berlin, Aktives Museum Faschismus und Widerstand, 1993), pp. 11-19; A. Frey, 'Ein Blümlein aufs Millionengrab', in Büchten and Frey, Im Irrgarten, pp. 20-30; J. Meister, 'Die Neue Wache als "Ehrenmal deutschen 
heldischen Sterbens", in Büchten and Frey, Im Irrgarten, pp. 31-36; B. Spies, 'Aus einem unabgeschlossenen Kapitel', in Büchten and Frey, Im Irrgarten, pp. 37-44; and J. Tietz, 'Schinkels Neue Wache Unter den Linden: Baugeschichte 1816-1993', in C. Stölzl, ed., Die Neue Wache Unter den Linden: Ein deutsches Denkmal im Wandel der Geschichte (Berlin, Koehler \& Amelang, 1993), pp. 9-93.

19 After its construction in 1701, Berlin's City Palace was altered and extended by various Prussian electors and crown princes. Berlin was the first seat of a court to create a street that doubled as a parade ground. See W. Braunfels, Urban design in western Europe: regime and architecture, 900-1900, trans. K. Northcott (Chicago, University of Chicago Press, 1988).

20 Even after this time, the Brandenburg Gate continued to symbolize the coming of a new leader, state or era. See B. Ladd, The ghosts of Berlin: confronting German history in the urban landscape (Chicago, University of Chicago Press, 1997), pp. 70-81.

${ }^{21}$ Under French occupation, administrative, judicial and legal systems were reorganized. Educational reforms were made and feudal social relations abolished. In 1819, the Prussian king reversed some of the economic reforms he had previously made (see M. Fulbrook, A concise history of Germany, Cambridge, Cambridge University Press, 1990, esp. pp. 95-104).

22 Karl Friedrich Schinkel (1781-1841) had such a strong impact on Berlin's urban morphology that he has been compared to Paris's Baron von Haussmann. After the Napoleonic period, Schinkel, who was known for his paintings and theatre sets of romantic landscapes and Gothic buildings, moved to classical designs, perhaps because Prussian leaders 'preferred the systematic, stabilising and ceremonial language of antiquity to the nationalist associations aroused by the Gothic' (P. Betthausen, 'Karl Friedrich Schinkel: a universal man', in M. Snodin, ed., Karl Friedrich Schinkel: a universal man, New Haven, CT, Yale University Press, 1991, p. 5). As demonstrated by Schinkel's later works, Gothic designs remained a source of inspiration. See Braunfels, Urban design, pp. 212-20; H. R. Hitchcock, Architecture: nineteenth and twentieth centuries (New York, Penguin, 1990), pp. 57-67; H. G. Pundt, Schinkel's Berlin: a study in environmental planning (Boston, Harvard University Press, 1972); and Snodin, Karl Friedrich Schinkel.

${ }^{23}$ For a history of the landscape ideal based upon the certainties of geometry, see D. Cosgrove, 'Prospect, perspective and the evolution of the landscape idea', Transactions of the Institute of British Geographers n.s. 10 (1985), pp. 45-62; and S. Daniels and D. Cosgrove, 'Spectacle and text: landscape metaphors in cultural geography', in J. Duncan and D. Ley, eds, Place/culture/representation (New York, Routledge, 1993), pp. $57-77$.

${ }^{24}$ J. Gillis, 'Introduction', in Gillis, ed., Commemorations: The politics of national identity (Princeton, Princeton University Press, 1994), pp. 1-35. See also J. Winter, Sites of memory, sites of mourning: the Great War in European cultural history (Cambridge, Cambridge University Press, 1995); and M. Heffernan, 'For ever England: the Western Front and the politics of remembrance in Britain', Ecumene 2 (1995), pp. 293-324.

25 M. Warner, Monuments and maidens: the allegory of the female form (New York, Atheneum, 1985). See also Johnson, 'Cast in stone'; G. Mosse, Nationalism and sexuality (Madison, University of Wisconsin Press, 1985); and A. Parker, M. Russo, D. Sommer, and P. Yaeger, eds, Nationalisms and sexualities (New York, Routledge, 1992). For a discussion of German First World War commemorations, see G. Mosse, Fallen soldiers: reshaping the memory of the world wars (New York, Oxford University Press, 1990); and R. W. Whalen, Bitter wounds: German victims of the Great War, 1914-1939 (Ithaca, NY, Cornell University Press, 1984). 
26 Winter, Sites of memory.

27 Mosse, Fallen soldiers, p. 87. 'Emperor's oaks' had also been planted throughout the nation after 1815 to celebrate the victory over France.

28 For a discussion of how individuals may have bodily experienced classical Roman cities, see R. Sennett, Flesh and stone (New York, Vintage, 1995).

29 Whalen, Bitter wounds, p. 185.

30 H. Marcuse, 'The national memorial to the victims of war and tyranny: from conflict to consensus', paper presented at the annual German Studies Association Conference, 25 Sept. 1997, Washington, DC. (MS available from Dept of History, University of California at Santa Barbara, CA 93106, USA).

31 The two large memorials to the fallen soldiers at Tannenberg (1927) and Schlageter (1931) were also identified by their crosses. See K. Hoffmann-Curtius, 'Das Kreuz als Nationaldenkmal: Deutschland 1814 und 1931', Zeitschrift für Kunstgeschichte 48 (1985), pp. 77-100; Meister, 'Die Neue Wache als "Ehrenmal"'; and Tietz, 'Schinkels Neue Wache', esp. pp. 62-74.

32 The 1957 East German memorial was designed by the architect Heinz Mehlan.

33 The Mahnmal as a type of memorial was built in the 1950 s and 1960s in the East, and in West Germany many were built under the Brandt administration during the late 1960s and 1970s. To my knowledge, no one has written a history of this type of memorial in German memory. See C. Heinrich, Strategien des Erinnerns: Der veränderte Denkmalbegriff in der Kunst der achtziger Jahre (Munich, 1993); R. Koshar, From monument to traces: German memory, 1870-1990 (Berkeley, Los Angeles and London, University of California Press, forthcoming); R. M. Roowaan, Die Unmöglichkeit von nationalem Gedenken: Die zentralen Denkmäler in der Bundesrepublik Deutschland, 1949-1993 (PhD thesis, Dept of Geography, University of Utrecht; Netherlands, 1997); and Till, Place and the politics of memory.

34 For a discussion of the rhetoric of the 'second Cold War', see S. Dalby, Creating the second Cold War (New York, Guilford Press, 1990).

35 See James Young, The texture of memory: Holocaust memorials and meaning (New Haven, CT, Yale University Press, 1993).

36 The 1969 inner room was designed by Lothar Kwasnitza. See also L. Demps, Die Neue Wache: Entstehung und Geschichte eines Bauwerks (Berlin, Militärverlag der Deutschen Demokratischen Republik, 1988).

37 From what I could discern, the state promoted this idea in the $1960 \mathrm{~s}$, and the tradition was picked up by citizens. See F. Wengler, 'Die Hochzeitspaare am Mahnmal Unter den Linden: Besinnliche Minuten bei einem schönen Brauch', Berliner Zeitung, 29/30 Jan. 1983.

38 Gewaltherrschaft cannot be directly translated into English, but in general it means 'tyranny'. It also refers to the violence and oppression of a patriarchal dictatorship.

39 C. Stölzl, 'Vorwort', in Stölzl, ed., Die Neue Wache, p. 7.

40 This official attempt to get rid of the communist past through the immediate destruction of memorials, the replacement of East Berlin street-names, and other acts was heavily criticized by East and West Berliners. See De Soto, '(Re)inventing Berlin'. Thanks to Heike Alberts for reminding me of this point.

41 To get a sense of the most pervasive arguments made about the memorial, I analysed newspaper articles from the national papers Die Zeit and Frankfurter Allgemeine Zeitung (both mainstream/conservative papers that provide the best coverage of cultural topics in Germany and are published in the media centre of Frankfurt), and from the local publications of die tageszeitung (a West German, left-wing paper) and Berliner Zeitung (a former East German publication viewed as mainstream) from Jan. to Nov. 
1993. For articles published from Nov. 1993 to Nov. 1994, I used the public relations archives of the Deutsches Historisches Museum in Berlin, the umbrella institution responsible for the maintenance and administration of the memorial. I also used materials collected and printed in the newsletters of the citizen initiative Aktives Museum Faschismus und Widerstand Berlin, e.V. (available at Chausseestr. 8, 10115 Berlin). In addition to participant observation at the memorial in 1994 and 1997, I conducted informal interviews with the director of the Deutsches Historisches Museum in June 1997; with members of the Aktives Museum in the spring of 1994 and in the summer of 1997; in 1993 and 1994 with the director of the German Gedenkstättenreferat (an umbrella organization that coordinates and publishes information about activities related to memorial museum centres); and with a member of the expert commission reviewing the proposals for the Holocaust Memorial in 1997. All interviews were conducted in Berlin.

42 There is a vast literature about these concepts. See T. Adorno, 'Was bedeutet: Aufarbeitung der Vergangenheit', in G. Kadelback, ed., Erziehung zur Mündigkeit (Frankfurt a.M, 1972), pp. 10-28; J. Habermas, The new conservatism: cultural criticism and the Historians' Debate, ed. and trans. S. W. Nicholsen (Cambridge, MA: MIT Press, 1989); M. Jay, 'Once more an inability to mourn? reflections on the left melancholy of our time', German Politics and Society 27, pp. 69-76; M. Kittel, Die Legende von der 'Zweiten Schuld'; Vergangenheitsbewältigung in der Ära Adenauer (Berlin, Ullstein, 1993); and P. Reichel, Politik mit der Erinnerung: Gedächtnisorte im Streit um die Nationalsozialistische Vergangenheit (Munich, Hanser, 1995).

43 About the distinctions between Western private/public spheres and communist state/family realms, see N. Funk and M. Mueller, eds, Gender politics and post-communism: reflections from Eastern Europe and the former Soviet Union (New York, Routledge, 1993). Because the social functions of memorials differed between East and West Germany, East Germans may have had different attitudes towards the meaning of the Neue Wache and therefore also not participated. In addition, the economic and psychological realities of unification were difficult for many East Germans who may not have had the time or energy to participate in these debates. Certainly this is a topic that warrants future research.

44 Quoted in A. Kugler, 'Ein Mahnmal für Opfer und Täter zugleich', die tageszeitung, 30 Jan. 1993, p. 40.

45 Social Democrats Peter Conradi and Freimut Duve, quoted in dpa, 'Gefallen, ermordet, vergast, umgekommen', die tageszeitung, 30 June 1993, p. 20. Peter Conradi was strongly opposed to both the Neue Wache and the 1980s proposal to establish a war memorial in Bonn. See also 'Die Debatte des deutschen Bundestages am 14. Mai 1993 zur zentralen Gedenkstätte Neue Wache', in Stölzl, Die Neue Wache pp. 212-22.

46 M. Niroumand, 'Das Einerlei der Opfer', die tageszeitung, 1 Feb. 1993, p. 10.

47 R. Koselleck, 'Stellen uns die Toten einen Termin?', Frankfurter Allgemeine Zeitung, 23 Aug. 1993, p. 29.

48 The changing nature of party politics since the 1980s and again after unification has become a topic of study in political science that is beyond the scope of this paper. See D. Conradt, G. Kleinfeldt, G. Romoser and C. Soe, eds, Germany's new politics: parties and issues in the 1990s (Oxford, Providence, 1995); H. Oberreuter, ed., Parteiensystem am Wendepunkt? Wahlen in der Fernsehdemokratie (Munich, Olzog, 1996); D. Roth, 'Some empirical findings on the transition process of German parties', American Institute for Contemporary German Studies conference report, in Washington, DC, 25 June 1996 (Baltimore, Johns Hopkins University Press, 1996), 
pp. 1-21; and T. Scharf, The German Greens: challenging the consensus (Oxford, Berg, 1994).

49 Interviewees critical of the memorial stated that the Council of Jews gave support to the Neue Wache only after the Chancellor agreed to establish a separate Holocaust Memorial that would commemorate the memory of Jews.

${ }^{50}$ I could not find out the position of other victim groups, such as the Associations of Persecuted Homosexuals, Victims of Euthanasia-Politics, or Persecuted Mentally and Physically Handicapped, or of related groups such as the Anti-Fascist Committee of the International League for Human Rights. See Marcuse, 'The national memorial'.

51 The literature on the 'Historians' Debate' (Historikerstreit) is enormous. See P. Baldwin, ed., Reworking the past: Hitler, the Holocaust, and the Historians' Debate (Boston, Beacon Press, 1990); and C. Maier, The unmasterable past: history, Holocaust, and German national identity (Cambridge, MA, Harvard University Press, 1988).

${ }^{52}$ Key articles include: D. Bartetzko, 'Luxuriöse Trauer, richtungslos schweifender Humanismus', Frankfurter Rundschau, 18 Feb. 1993; E. Beaucamp, 'Der Kleinmut der Enkel', Frankfurter Allgemeine Zeitung, 13 Mar. 1993; F. Dieckmann, 'Heldenbilder, Opfergedenken', Frankfurter Allgemeine Zeitung, 1 July 1993; C. Fischer-Defoy, 'Wir brauchen viele Denk-Orte', Berliner Zeitung, 15 Feb. 1993; A. Diamant, 'Ein Denkmal für die Opfer', Allgemeine jüdische Wochenzeitung, 9 Sept. 1993; M. de Michelis, 'Jedes Mehr ein Zuviel', Die Zeit, 16 July 1993, p. 42; R. Koselleck, 'Bilderverbot: welches Totengedenken?', Frankfurter Allgemeine Zeitung, 8 Apr. 1993, and 'Stellen uns die Toten'; Kugler, 'Ein Mahnmal'; 'Späte Debatte über das Mahnmal Neue Wache', die tageszeitung, 5 May 1993, p. 38.

${ }^{53}$ For a discussion of the history of changing relationships between the local and the national in Berlin, see S. Campbell, Cold War metropolis.

54 Both the American historian Marcuse and Christine Fischer-Defoy (the president of the Active Museum) date the Neue Wache controversies to the Bonn memorial debates. C. Fischer-Defoy, 'Wider den kollektiven Gedächtnisverlust', in Büchten and Frey, Im Irrgarten, pp. 7-8; Marcuse, 'The national memorial'. For a discussion of the proposed history museums, see Maier, The unmasterable past, and Till, Place and the politics of memory.

55 L. Rosh, 'Unser Kanzler hatte (k)eine Idee', Vorwärts, 31 Aug. 1985.

56 Till, Place and the politics of memory. See also Fulbrook, Divided nation; Garton Ash, In Europe's Name; and H. A. Winkler, 'Rebuilding of a Nation', Daedalus 123 (1994), pp. 107-27.

57 Quoted in R. Wolin, 'Introduction', to Habermas, The new conservatism, p. xiv.

58 The idea of an 'appropriate past' is well discussed in E. Hobsbawm, 'Introduction: inventing traditions', in Hobsbawm and T. Ranger, eds, The invention of tradition (Cambridge, Cambridge University Press, 1983), pp. 1-14.

59 The group, headed by Hamburg businessman Wilhelm von Boddien and with the support of many local and national officials, would like to replace the Palace of the Republic, and to reconstruct at least the exterior wall of the Hohenzollern Palace. During the time the trompe-l'ail stood, an exhibition displayed the history of the palace, the proceeds of which went toward the reconstruction. See C. Whitney, 'Trompe-l'eil palace from Berlin's past', International Herald Tribune, 14 July 1993, p. 18.

${ }^{60}$ See Ladd, Ghosts of Berlin.

61 C. Stölzl, 'Die Trauer der Mutter: Plädoyer im Denkmalsstreit um die Neue Wache: Sprechendes Mitleid statt sprachlosem Stein', Frankfurter Allgemeine Zeitung, 13 Mar. 1993.

${ }^{62}$ Articles in the alternative exhibition book by the Active Museum Berlin on this theme 
included: K. Hoffmann-Curtius, 'Ein Mutterbild für die Neue Wache in Berlin', in Büchten and Frey, Im Irrgarten, pp. 60-63; and S. Wenk, 'Die überdimensionierte Mutter als Symptom?', in Büchten and Frey, Im Irrgarten, pp. 64-68.

63 Koselleck, 'Stellen uns die Toten'.

${ }^{64}$ For a discussion of the role of women as active participants in the Third Reich, see C. Koonz. Mothers in the Fatherland: women, the family and Nazi politics (New York, St. Martin's, 1987). Thanks to Tom Lekan for raising this point in personal conversations.

65 'Whereas women were proportionately represented among the unemployed in mid1990, by June 1992 they accounted for $63.6 \%$ of the registered jobless. $10 \%$ of men were unemployed, compared with $18.9 \%$ of women' (H. M. Nickel, 'Women in the German Democratic Republic and in the new federal states: looking backward and forward (five theses)', in Funk and Mueller, Gender politics and post-communism, pp. 138-150 (quote n. 27, p. 149)). See also R. Berger et al., 'Offener Brief an die Bundestagspräsidentin Frau Prof. Dr. Rita Süssmuth', in L'Homme: Zeitschrift für feministische Geschichtswissenschaft 4 (1993), pp. 97-99. It should be noted that many GDR women did not hold management positions and were confined to certain sectors; some jobs were 'held' by more than one person because of the official policy of unemployment. See Dodds and Allen-Thompson, The Wall in my backyard.

66 Germany is not the only country to discuss the demographic make-up of its population in these terms. Similar discussions can be found in England and the US.

67 Christian Stroebele, quoted in Kugler, 'Ein Mahnmal'.

68 Quote from Volksbund deutsche Kriegsgräberfürsorge, 'Aide Mémoire', 8 May 1983, in Marcuse, 'The national memorial'.

${ }^{69}$ Chancellor Helmut Kohl, quoted in A. Rabinbach, 'The Jewish Question in the German Question', in P. Baldwin, Reworking the past, p. 60.

70 Maier, The unmasterable past. For a discussion of the controversies surrounding Bitburg, see G. Hartman, ed., Bitburg in moral and political perspective (Bloomington, Indiana University Press, 1986).

71 Koselleck, 'Stellen uns die Toten'.

72 To the far left and right sides of the memorial are translations of this text in English, French, Dutch, Russian, Polish, Spanish, Japanese, and Turkish. To the immediate left of the entrance to the interior room is a brief history of the Neue Wache.

73 Marcuse, 'The national memorial'. Compare this text to 'Speech by Richard von Weizsäcker, President of the Federal Republic of Germany, in the Bundestag during the ceremony commemorating the 40th anniversary of the end of the war in Europe and of National Socialist tyranny, May 8, 1985', in Hartman, Bitburg, pp. 262-73.

${ }^{74}$ W. Jens, 'Offener Brief an den Bundeskanzler Dr. Helmut Kohl' (8 Feb. 1993) repr. in Stölzl, Die Neue Wache, pp. 189-90; V. Schmidt-Lisenhoff, "Ein schlimmes Symptom": Käthe Kollwitz in der Neue Wache', in Büchten and Frey, Im Irrgarten, pp. 69-74.

75 Akademie der Künste, Streit um die Neue Wache: Zur Gestaltung einer zentralen Gedenkstätte (Berlin, Akademie der Künste, 1993).

76 The term 'postmodernism of resistance' is contrasted to a 'postmodernism of reaction' in H. Foster, 'Postmodernism: a preface', in Foster, ed., The anti-aesthetic: essays on postmodern culture (Seattle, Bay Press, 1983).

77 Withers, 'Place, memory, monument'.

78 Marcuse, 'The national memorial'.

79 See T. Cresswell, In place/out of place: geography, ideology, and transgression (Minneapolis, University of Minnesota Press, 1996). 